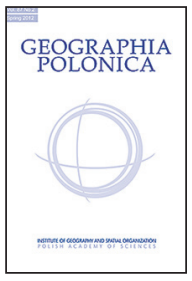

\title{
WARSAW URBAN-RURAL REGION - AN ALTERNATIVE DEVELOPMENT PERSPECTIVE?
}

\section{Ewa Korcelli-Olejniczak}

Institute of Geography and Spatial Organization

Polish Academy of Sciences

Twarda 51/55, 00-818 Warsaw: Poland

e-mail address: eko@twarda.pan.pl

\begin{abstract}
In this article questions are posed concerning the spatial structure of the Warsaw region and its development trends. These are presented against recent conceptual approaches to the study of metropolitan regions. Alternative hypotheses are discussed related to continuing spatial polarization, the emergence of polycentric urban patterns, as well as growing functional interdependence between the urban and the predominantly rural areas within the region. This is placed in the context of public policy objectives concerning both territorial cohesion and socio-economic growth; the latter hidden under the region's competitiveness label. Empirical findings from a comparative analysis of the location behavior of selected firms in the advanced services sector are referred to in the discussion. It is argued that in projecting the region's development path into the future, the concept of the urban-rural region is of particular relevance. Such an approach may also be adopted for use in developing spatial policy.
\end{abstract}

\section{Key words}

metropolitan region $\bullet$ urban-rural region $\bullet$ the Warsaw region $\bullet$ advanced service sector $\bullet$ territorial cohesion

\section{Introduction}

Urban regions, in a similar manner to the national settlement systems of which they are a part, may be evaluated according to various indicators related to cohesion, competitiveness and environmental sustainability levels (ESPON 2004). The cohesion versus competitiveness dilemma constitutes one of the standard points of reference within the range of spatial development issues. It covers a broad spectrum of scale, from sub-regional to global, and is interpreted in both positive and normative terms. There is also a tendency to reconcile these two policy objectives, which are traditionally regarded as mutually conflicting (ESPON 2006).
This can be achieved by selecting alternative priorities during successive phases of development (Benz et al. 2004) or by attaching cohesion and competitiveness related goals to different territorial dimensions.

The latter approach is adopted in Poland's National Spatial Development Concept (MRR 2012). According to this document international competitiveness - one of the strategic goals of spatial development at the national level - can be enhanced by strengthening the metropolitan centers by interconnecting them with functionally integrated networks. Conversely, the goal of territorial cohesion is conceived in terms of facilitating the participation of the inhabitants of various parts 
of the country in the development process. Cohesion oriented policy measures should focus on (a) peripheral regions, (b) rural areas and sub-regional centers situated within the zones of influence of the major cities, and (c) selected areas suffering from poor accessibility, deficits in the sphere of public services, as well as from social degradation. In the present paper the emphasis is put on the second of the three dimensions identified above. It is thus claimed that reconciliation of the national territorial development objectives of cohesion and competitiveness, can, and should primarily, be sought at the level of metropolitan regions.

When spatial patterns of socioeconomic change observed during the last two decades are looked at from the national perspective, it is the capital city of Warsaw, with its overall dynamics, that is regarded as the main carrier of the transformation and development processes. This has been confirmed by a number of research studies (see, for example: ESPON 2004; IKER 2008, Śleszyński 2007), which document the role of Warsaw as by far the most important center among Polish cities with respect to advanced, specialized functions, including business control and knowledge-based activities, in addition to public administration and high-ranking public services.

Also the Mazowieckie Voivodship - the region of Warsaw (5.3 million inhabitants, out of which 1.7 million are inhabitants of the city of Warsaw and 1.5 million of its metropolitan ring) ranks first among Poland's administrative regions in most of the major socio-economic development indicators. At the same time, however, that region is characterized by the largest disparities between its urban core and the remaining areas. It is a plausible assumption that the structural weakness of the hinterland has an adverse impact upon Warsaw's image, and hence upon its overall positioning among European metropolitan cities.

In this context some research can be suggested and policy-relevant questions can be posed. One of these concerns the prospects and conditions for the growth of cohesion within the Warsaw region, i.e. its functional integration and internal interdependence, which are diagnostic features of developed metropolitan regions. Another question concerns the impact such a trend could have on the external competitive position of both the capital city, and the region as a whole. The importance of city-region relations, including regional co-operation for economic growth at the metro- politan scale, was emphasized by Bourne (1999), among other authors.

When addressing these questions it is appropriate to refer to the concept of the metropolitan region and its recent developments. These are outlined in the section below. Generalizations concerning the spatial structure of the region arrived at in selected earlier studies are overviewed in section three. Section four presents the results of a comparative enquiry, conducted by the author, focusing on the location behavior of firms based in Warsaw and its hinterland which fall into the category of advanced services. The final section contains a discussion on conceivable future trends using the empirical material presented as a basis. This includes some evaluation of the officially adopted regional development strategy with its emphasis on polycentric development patterns.

\section{Metropolitan regions in evolution}

The concept of the metropolitan region, whose origins are traced back to the work of Gras (1922) and McKenzie (1933), has undergone an evolution marked in the course of the following decades by periods of development, retreat, and rediscovery. Its emergence was related to the growing role of the metropolis which, in the words of Berry and Horton (1970: 257): "by 1950 had come to dominate the social and economic organization of a technologically advanced society".

In a study that provided the benchmark for subsequent analyses of the structure of metropolitan regions, Bogue (1949) identified their several basic dimensions. These included profiles of the population distribution, as well as of the intensity of economic activities, related to distance from the metropolitan center; the presence of subdominant centers, and differentiation of spatial patterns by type of sector: local, subdominant and inter-metropolitan. Metropolitan regional dominance was interpreted by Bogue in terms of 'control through interdependence', a kind of symbiotic relationship, one in which the metropolis grows and thrives on the basis of the functions which it provides for its hinterland. Such functions comprise both a wide spectrum of higher order service activities, as well as the collection, shipment and processing of primary goods produced within the hinterland area. As they represented "a standard form of social organization", the metropolitan 
regions were assumed to cover the entire national territory (Bogue 1949: 13).

The rule of assigning each territorial unit to one a priori selected metropolitan center was questioned by Duncan et al. (1960: 248-251) who indicated the existence of often overlapping and discontinuous patterns of city-hinterland connections which may be "too complex to be presented on a single map". This pointed to the relative nature of metropolitan regional dominance. Actually, Duncan et al. identified several types of metropolitan centers, according to the character of their regional relationships.

In later periods the focus of research on metropolization processes in space shifted from the regional to the local scale. This reflected the growing role of suburbanization phenomena and the increase in the range of commuting to central cities from the surrounding zones. Metropolitan areas were defined as statistical units, while the concept of the metropolitan region became overshadowed, and to some extent replaced, by more recent notions, in particular those of urban field (Friedmann \& Miller 1965) and daily urban systems (Berry 1973), as well as that of functional urban regions (Hall et al. 1973). According to the latter concepts, along with improvements in transportation and the increasing spatial mobility of the population, the expanding daily commuting fields tend to coalesce with the extent of urban-metropolitan hinterlands, as determined by the range of commodity, information, and migration flows.

Parallel to these trends, the progressive integration of urban systems was reflected by increasing interaction and interdependence within the networks of metropolitan cities at both national and international level (Pred 1975; Dziewoński 1975; Friedmann 1986). This implied a weakening of their regional linkages, at least in relative terms. When quoting Batty (2008: 5): "in an increasingly globalized world large cities seemed, indeed are, often disconnected from their local hinterlands, and even the nations that contained them no longer seemed relevant to their functioning". The reverse side of such a change in relations between metropolis and region is the decreasing dependence of hinterland zones upon metropolitan centers, that is their gradual reorientation towards supra-regional networks by-passing the hierarchical mode of spatial organization.

The revival of the idea of metropolitan regions as important components of settlement systems, compatible with the development of spatial management, is connected with recent policy-relevant approaches to spatial organization, in particular the concepts of EMR - the European Metropolitan Regions (Aring 2009), and of RUR - the RuralUrban Regions (Piorr et al. 2011).

In the EMR concept it is assumed that specialized functions of metropolitan rank are shared between the main urban center and other parts of the region. In the case of polycentric regions, decentralisation of a wide range of economic activities permits the strengthening of secondary urban nodes. This leads to the formation of regional urban systems with largely non-hierarchical internal linkage patterns. It also implies a degree of balance in functional relations within the region. Such structures are interpreted as resilient and adaptive, supportive of innovation diffusion and contributing to the region's general competitiveness.

The concept of rural-urban regions (RUR; metropolitan regions of mono -and polycentric structure are among the morphological types identified) explicitly extends the regional boundaries beyond the range of intense daily interaction of the main center (or centers), so as to involve the rural hinterland zone, along with the urban and the peri-urban areas. Its functional role within the region, based to a large extent upon the environmental resources, is defined in reference to the idea of 'urban-rural partnership' postulated in the ESDP - European Spatial Development Perspective (1999). The RUR concept focuses on the growing importance of ecological values among factors determining the location of both residences and work places, and thus shaping the contemporary spatial patterns of human settlement.

It is indicated in this brief overview that the concept of the metropolitan region, the latter defined as a nodal region containing a large city together with a broad, contiguous zone dominated by the city's economic and social functions, has evolved with the changing course of contemporary urbanization processes. Once displaced to some degree by other notions, referring mainly to the extent of metropolitan daily mobility patterns, it has reemerged within the framework of subsequent, spatial policy-related approaches to the study of urban development.

Metropolitan regions, along with metropolitan cities and metropolitan areas, can be considered among the basic spatial manifestations and 
territorial dimensions of the metropolisation processes that appeared early in 20th century in the advanced economies of North America, and then Western Europe, as a consequence of technological progress and the ensuing economic and social change. Under globalization conditions they have spread at an accelerated rate to other regions of the World including Central and Eastern Europe. In this process, basically characterized by a sort of phase shift, catch-up development, the metropolitan region, when interpreted in terms of its spatial structure, may be seen to bifurcate from the original, classical form into several, parallel regional types (Korcelli-Olejniczak 2012).

The case of the Warsaw region, on which this paper is focused, serves to indicate the characteristics which the spatial structure of a large cityregion may assume during the socio-economic transformation process involving the advent and development of the market economy, and what further trends are likely to become dominant in this respect. Do they point towards progressive polarization, i.e. increasing disparities, with a growing dominance of the main urban center which tends to intercept specialized functions located in other towns within the region? Or, can factors of innovation diffusion-led, inter-regional decentralization be identified that bring about a revival of sub-regional centers so that the spatial structure of the region assumes a more or less polycentric form in concordance with the rules of territorial cohesion? Finally, would functional specialization of individual sub-regions, based upon endogenous factors including environmental resources, assure intra-regional complementarity, and a degree of cohesion under the prevalence of forces promoting spatial concentration?

\section{The Warsaw region as a metropolitan region in the making}

The role of metropolization processes in shaping settlement patterns in Poland has been recognized only during the last two decades. Nonetheless studies on city-hinterland relations and on the formation of urban regions have a longer tradition. Wróbel (1960), in a classical study on the Warsaw Voivodship as a nodal economic region, identified the region's internal hierarchical structure by referring to, among other things, central place functions. Eberhardt (1970), who analyzed the spatial range of influence of the major cities with respect to such spatial linkages as migration flows and student enrolment fields, found out that in the case of Warsaw that range covered most of eastern, as well as of central Poland.

While spatial concentration of the population, both of the total and of the urban population, has been a general trend in Poland since the postSecond World War period (Gawryszewski 2005), its impact upon settlement structure on a regional scale and upon city-region relations has varied over time reflecting shifts in sectoral and spatial policies at the state level. During the 1960s, antiurban expansion policies, which were intended to limit large-city growth, favored medium-sized cities, including those situated in the hinterland zones of large urban centers, for industrial locations (Dziewoński et al. 1977). These were often branch, or subsidiary plants of industrial establishments located in the major cities. During the 1970s state investments in industry, housing and transportation focused mainly on large urban conurbations; this in turn generated a rapid expansion in both the intensity and spatial range of commuting-to-work (Dziewoński \& Korcelli 1981). In the early 1990s the first phase of the systemic transformation brought about a weakening of cityhinterland linkages as a consequence of industrial restructuring together with a contraction of commuting fields. City-region relations were also influenced by the administrative reform of 1999 which involved a reduction in the number of voivodships, the upper level administrative units, from 49 to 16 . This led to a strengthening of the position of the major cities, the new voivodship capitals, vis-à-vis sub-regional centers. At the same time, it provided some preconditions for integration, or reintegration, of individual sub-spaces within the larger regions.

Studies conducted during the last two decades have focused on the role of large cities, i.e. metropolitan centers, in the transformation of the national spatial management, their changing functional profiles and the built environment, as well as on the physical expansion of metropolitan areas (Jałowiecki 1999; Parysek 2005; Markowski \& Marszał 2006; Liszewski 2010; Czyż 2011a). The division into metropolitan and non-metropolitan areas is considered to be the main dimension of contemporary territorial differentiation with respect to basic socioeconomic indicators (B. Domański 2008), although an alternative axis, 
one separating metropolitan regions from intermetropolitan regions, is also referred to (Heffner 2012). Such regions (or macroregions according to some authors) are normally identified with the new administrative regions - the NUTS2 level units.

Two development trends are generally emphasized with respect to the Warsaw region, namely a dynamic suburbanization in the metropolitan ring, with typical features of urban sprawl (GutryKorycka 2005; Lisowski 2010; cf. also Degórska 2012), and accumulation of phenomena characteristic of the metropolitan shadow zones in areas situated further out from the city, though still within the sphere of its dominant influence. It has been noted that some specialized service, as well as production, activities once carried out in smaller urban localities situated within the region tend to move their location to the metropolitan area (see, for example: Lisowski 2000). This trend is accompanied by migration of skilled labor and, as a consequence, contributes to an increase in intraregional disparities in income and unemployment levels as well as in the age distribution of the population.

These observations were corroborated by Gorzelak and Smętkowski 2005 (see also: Gorzelak 2007; Smętkowski 2007); in a systematic study based on empirical data for the regions of Warsaw, Poznań and Gdańsk. While providing evidence for gravitation of the hinterland zones towards the metropolitan centers, in particular within the domain of public services (in the sphere of health, culture, education), as well as for migratory movements, the authors emphasize the generally unbalanced character of the city-region relations. Positive interactions, i.e. spread effects, were found to be restricted mainly to the internal zones of the regions basically corresponding to the extent of metropolitan areas, i.e. daily urban systems. In the remaining parts, especially the socalled intermediate zones, functional city-oriented linkages were dominated by the backwash effects. They were also, to some degree, characterized by decreasing intensity. In general, when seen from the perspective of the metropolitan centers, the city-region interaction is interpreted as of diminishing importance relative to the growing role of intercity linkages at both the national and international level.

In the rural parts of metropolitan hinterlands the backwash effects are manifested first of all by negative demographic trends, which are mainly due to net migration losses and to an advanced degree of population ageing. Such trends predominate throughout the major part of the Warsaw region beyond the metropolitan ring, except for smaller islands characterized by population growth situated around sub-regional urban centers. The phenomenon of demographic decline is especially pronounced in the peripheral belt along the borders with the neighboring administrative regions (Rosner 2011). This pattern corresponds with the distribution of rural municipalities featuring a below-average level of educational attainment of the resident population, as well as an overall low development level when measured by a number of indicators reflecting economic activity and life quality (Bański 2011).

While differentiation between the metropolitan areas, intermediate, and peripheral zones represents a general feature of the spatial structure of metropolitan regions, there are a number of characteristics specific to the individual regions. These reflect to some degree the spatial variations in socioeconomic conditions, as well as in settlement patterns that appear at the macroregional level. Thus, Warsaw region, when confronted with Poland's other major metropolitan regions such as those of Poznań, Cracow and Gdańsk, exhibits a stronger internal polarization with a pronounced metropolitan shadow effect. As comparative studies carried out at a European scale (ESPON FOCl 2010a; see also: Smętkowski 2010) indicate, such characteristics, together with an increasing gradient of socioeconomic city-region disparities, are distinctive of capital city regions of the new EU member countries. According to the project report cited, these disparities are positively associated with the overall rate of economic growth, as well as with significant differences in the structure of economic activities between the metropolis and the surrounding region. The report (ESPON 2013, 2010b) concludes that the rapidly developing metropolitan areas, in particular those situated in predominantly rural, agricultural regions, tend to drain resources from their broader hinterlands. In the light of the report, the Warsaw region represents an exemplary case of such a kind of spatial relationship.

These results are in fact in line with some assumptions and expectations referred to earlier (Benz et al. 2004) concerning patterns and policies of territorial cohesion within the EU. Against these findings it should be noted that the growing intraregional polarization, while perhaps inevitable in the 
short term, must not be accepted as optimal in a long-term perspective. This position calls for continuation and extension of studies on location patterns of economic activity and functional linkages within the region. One such attempt, pertaining to service sector firms, is presented below.

\section{A case study on location factors and the spatial range of activity of advanced service sector firms}

It is generally recognized (Chojnicki 1988; Czyż 2011b) that functional linkages comprise a major dimension of the spatial structure of a territorial system; moreover, such linkages constitute the factor determining the system's performance. For the purpose of the present analysis the structure of the Warsaw metropolitan region (its extent is here assumed to correspond to the Mazowieckie Voivodship), which may be considered as a territorial system at regional level, is looked at via the location patterns and activity range of firms that are grouped within the category of advanced services. This research approach seems to relate to significant aspects of the region's spatial structure.

The main objective of the study (see Korcelli-Olejniczak 2010 for a more detailed account) is to identify spatial relations between the city of Warsaw and its surrounding region, as expressed in terms of a major category of urban functions (Hall \& Pain 2006). More specifically, the question is posed as to whether the location behavior of firms that is observed would permit one to speculate on a relative equilibrium appearing in city-hinterland relations. In designing the conceptual framework reference is made to the concept of European Metropolitan Regions (MKRO 2006) which puts an emphasis on the role of the metropolitan hinterland and its support in the region's striving for innovation, and hence for competitiveness (R. Domański 2000). This aspect of balancing the functional positions of the city and the region seems to be of particular importance in the context of global urban competition. The challenge can be met through development of non-hierarchical network relations within the metropolitan region, between urban places differing in size, as well as in functional profile.

The analysis is based on the micro-level approach; i.e. it is presumed that the decisive factor in the formation of the location patterns of enterprises is expressed by the sum of single, individual choices and solutions. The data used are derived from a special survey, which covered a set of 600 randomly selected firms, including three hundred units from the city of Warsaw, and the remaining 300 firms from other parts of the region. This was a computer aided telephone interview survey based on a questionnaire designed by the author of the present study. The survey comprised a part of a broader inquiry concerning the region of Warsaw, carried out in 2009 for the purpose of the EU's 6th Framework PLUREL project on Peri-urban Land Use Relationships. For firms with a city of Warsaw location the survey success rate was approximately 80 percent (nearly 370 firms were initially approached); for those located in other municipalities it was 60 percent (contacts were made with about 600 firms).

Altogether, firms located in 106 out of the total of 314 municipalities in the Mazowieckie voivodship were represented in the sample (Fig. 1). There were ten kinds of activities chosen among those in the advanced services category, namely: private higher education, information technology, sports and recreation, transportation and logistics, legal services, investment and other business consultancy, advertising, market and public opinion research, telecommunication services, as well as other selected services, including those performed by language schools and travel agencies.

At the first stage of the investigation five indicators were used in order to identify specific characteristics of the firms located in the region outside of the capital city, as opposed to the Warsawbased enterprises. The measures in question were related to the structure and market situation of firms, namely: the number of employees, value of annual turnover, market range (according to the origin of the customers), location of cooperating firms, and general level of interaction of firms. While small and medium size firms, i.e. those with less than 50 employees, represented a clear majority of all the enterprises interviewed, their share was somewhat higher in the case of the city of Warsaw. The region-based firms were also, on average, larger with respect to annual turnover.

The spatial range of the firms' activities is to a considerable degree related to their territorial positioning within the region. In the case of all the Warsaw-based, and approximately one half of the hinterland-based enterprises included in the survey, the services were provided in the region's core city. However, firms of the latter group oper- 


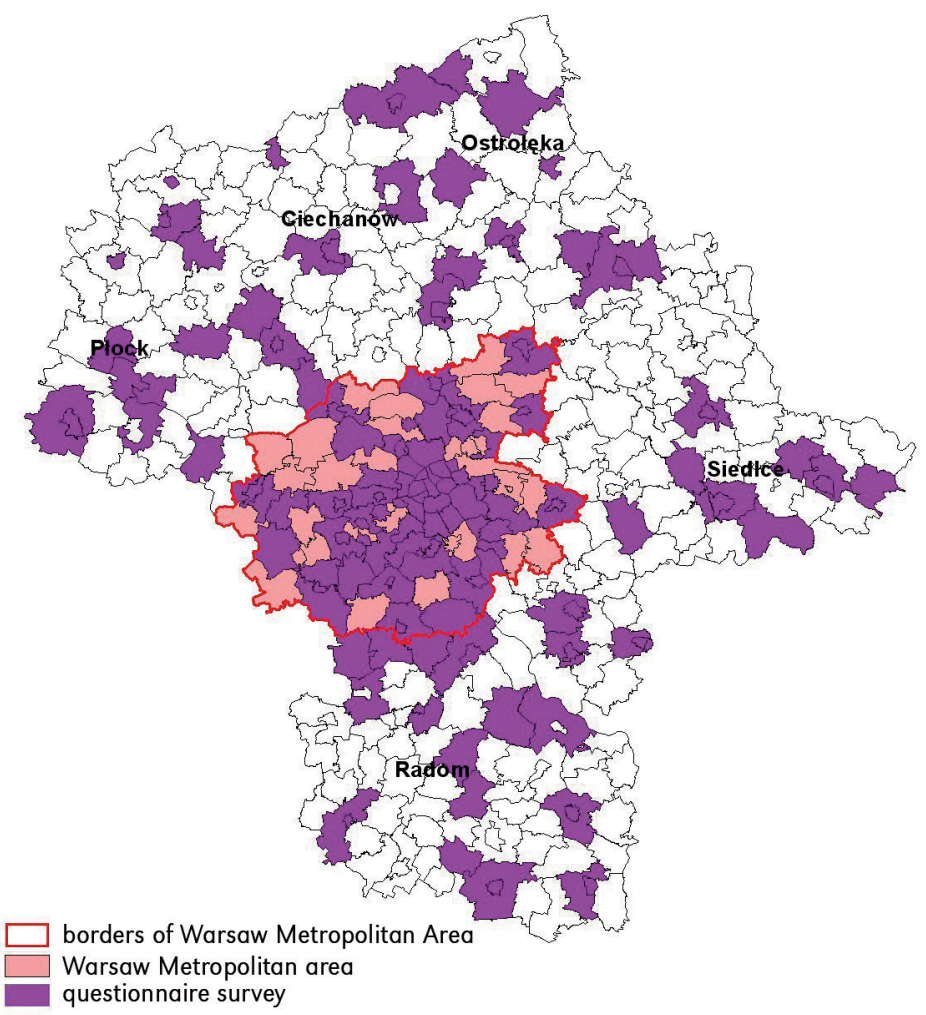

Figure 1. Location of companies investigated.

ated mainly in the peri-urban and rural areas, as well as in small and medium sized towns of the Mazovia region. For firms located in Warsaw the regional hinterland constituted a part of their market area in two out of three cases. Among these enterprises a majority (some 60 percent) operated in other regions (i.e. voivodships) as well; this was less frequently true for the hinterlanbased firms, more than 50 percent of which concentrated their activity within the region.

In general terms, a rather straightforward, distance-decay relationship can be observed with respect to the Warsaw-based firms where a decreasing number of units report in their market ranges the city, the metropolitan area, the region and other regions. The pattern was somewhat different for the firms situated in other municipalities in the region; namely, their market linkages were contained primarily within the Mazowieckie voivodship, though about 50 percent of all enterprises still indicated the city of Warsaw, the metropolitan area, and/or the other regions (voivodships), respectively (Fig. 2).

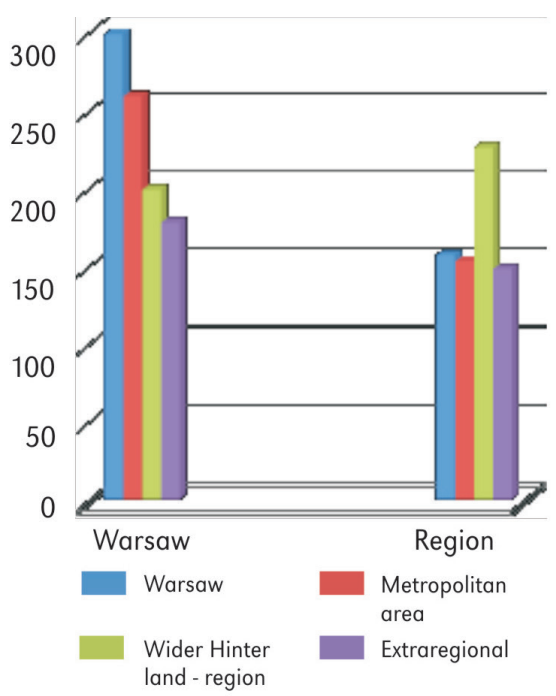

Figure 2. Range of interaction of Warsaw-based and region-based firms. 
The pattern of inter-firm cooperative linkages broadly resembled that of the range of the firms' market areas. For Warsaw-based enterprises the local, i.e. intra-city links were dominant, which may seem obvious due to the large concentration of firms in the respective category and a high sions. Although the general propensity to change location was similar for the Warsaw-based and the hinterland-based firms, the decisions to locate and relocate were attributed to a different mix of factors within the two groups of enterprises (Tab. 1). Accessibility to customers, which was

Table 1. Leading location factors indicated by Warsaw-based and region-based firms.

\begin{tabular}{|c|c|c|}
\hline $\begin{array}{c}\text { Factor } \\
\text { No. }\end{array}$ & Warsaw-based firms & Region-based firms \\
\hline 1 & accessibility to customers & accessibility to customers \\
\hline 2 & proximity to owner's place of residence & time-distance to major transportation routes and airport \\
\hline 3 & development potential of Warsaw & nearness of Warsaw \\
\hline 4 & presence of other firms In the given branch & proximity of suppliers and cooperating firms \\
\hline 5 & business infrastructure & availability and price of land \\
\hline 6 & prestige & \\
\hline
\end{tabular}

density of potential business contacts. Similarly, the hinterland-based firms were most frequently entering into cooperation with other enterprises located in the Mazovia region. Interestingly enough, the presence of inter-firm linkages was reported by a higher share of firms (60 to 42 percent) with an out-of Warsaw location. At the same time, among all firms surveyed those firms located in the regional hinterland more often admitted to maintaining cooperative business contacts at an international level.

The second stage of analysis aimed at identifying the specific characteristics of those firms that have changed their location over the last few years. Their share of the total number of firms covered in the survey amounted to 40 percent. This proportion was in fact equal for the Warsaw-based and the hinterland-based units. Location change was observed relatively frequently among those firms, which reported their market range to be predominantly local and regional. In the case of Warsaw-based firms the moves were predominantly contained within the administrative limits of the city, while in the hinterland they typically involved the relocation of firms from one urban location to another within the region. There were more moves out of Warsaw than into the city. The former included both short-distance location shifts within the metropolitan area, as well as relocations towards more distant, small and medium-sized urban centers in the region's hinterland zones.

The third part of the study looked at the factors responsible for location and relocation deci- identified as the most important factor in general, was indicated by almost 80 percent of respondent firms from the city, and by 30 percent of firms in the hinterland. Proximity to the owner's place of residence, factor number two in the case of firms located in Warsaw, turned out to be relevant for only one out of six hinterland-based enterprises. Instead, firms in the latter group frequently pointed to measures of spatial accessibility - nearness to the region's core city, time-distance to major thoroughfares, proximity to the airport. Conversely, for firms situated in Warsaw factors related to economies of agglomeration and urbanization, including the presence of other firms in the same branch, as well as business infrastructure, prestige and development potential, were listed among the most important determinants of location decisions.

The firms that have changed their location during the last few years indicated the particular role of their location vis-à-vis major transport routes and of operating costs (for Warsaw-based firms), as well as proximity to cooperating firms - for both groups of enterprises, but especially those in the hinterland zones. These factors were attributed the highest frequency, as expressed in factor coefficient values (Korcelli-Olejniczak 2010: 585). The importance of the latter location factor may point to the formation of local networks of firms. Such networks of inter-firm production linkages tend to develop both within the Warsaw metropolitan area, and in the region's more distant hinterland zones. 
On the basis of the results of the survey on the direction in which firms are relocating one may conclude that there is a certain measure of balance beginning to emerge in this respect between the core city and the rest of the metropolitan region. Firms' location moves tend to assume a multilateral rather that a unilateral character. Some enterprises originally operating in the region's outlying zones now find their new locations in the Warsaw metropolitan ring. At the same time, other firms depart from the city for smaller urban settlements in the hinterland in search of lower operating costs. Their decisions to relocate are supported by improvements in transportation accessibility, the availability of modern telecommunications infrastructure, and by growing local demand for advanced services, both consumer and producer generated.

Some conclusions concerning relations between the metropolitan city and the surrounding region can also be derived from the analysis of the range of activities of the firms. The data collected in the course of the study show that organization of economic activity in the metropolitan region is not simply related to spatial accessibility with respect to the urban core. For many specialized services produced in the hinterland region, Warsaw is neither the main recipient, nor a major intermediary. A considerable proportion of these activities are oriented towards local, as well as extra-regional markets. There are signs of inter-firm linkages in these areas consolidating into cooperative networks, which can lead to an increase in the local development potential. This may mark a certain change occurring in trends towards the evolution of economic relationships between the city and the region, even though it is not translated into changes in spatial patterns of socioeconomic indicators at the macro level.

The format of the data available for the purpose of the analysis imposes a number of limitations upon the scope of possible generalizations concerning both the spatial patterns of firms' activities and their tendency to relocate. The most restricting in this respect seems to be the dichotomous division of the region into the city of Warsaw and the rest of the voivodship. Such a way of aggregating data does not allow us to identify systematic distinctions in the behavior of firms located within the metropolitan ring as opposed to those located in other parts of the hinterland area, including sub-regional centers and rural zones. Another limitation stems from the lack of disaggregation of the firms investigated into subcategories, i.e. different activities that may, and most certainly do exhibit specific preferences both with respect to location, as well as patterns of spatial interaction.

\section{Discussion and conclusions}

Territorial cohesion related objectives rank high among the development goals that are outlined in the regional policy strategy documents of the Mazowieckie Voivodship (SWM 2006). It is recognized that the intraregional disparities observed constitute a barrier to the general socioeconomic development of the Warsaw region as a whole. The increase in territorial cohesion anticipated by the planners by the year 2020 is to be based in particular on economic stimulation of the region's peripheral zones. This, in turn, can be achieved by supporting the development of selected urban centers of sub-regional level, via, among other things, their physical revitalization, the upgrading of public services and improvements in transportation infrastructure. More specifically, five former (i.e. before the 1999 administrative reform) voivodship capitals: Radom, Płock, Siedlce, Ostrołęka and Ciechanów; now situated within the borders of the Mazowieckie voivodship, are identified in the spatial policy documents as nodes of a polycentric regional settlement pattern. Their future development is seen to be based on endogenous factors combined, through synergy effects, with decentralization, i.e. the spread of selected economic activities from the region's core areas.

The validity of the polycentric development scenario for the Warsaw region may, however, be questioned in the light of recent empirical evidence (Komornicki et al. 2012) which documents the lack of any notable interactions among the above listed sub-regional centers, in addition to the weaknesses of their current economic base. At the same time, recent studies point to the role of those urban centers, as well as of a score of other, more or less regularly distributed middlesized towns, centers of poviats and administrative units of intermediate level, in the organization of economic and social activity at sub-regional and local levels.

The latter observation is in line with the findings derived from the analysis of the locational behavior of firms in the advanced services sector indicating 
the importance of the formation of local, inter-firm cooperative linkages. On this basis it seems justified to suggest that the search for territorial cohesion at intra-regional level can be directed towards the development of networks of enterprises situated in, and around, small and medium-sized urban settlements in the region's hinterland. For such a phenomenon to be sustained, certain incentives and conditions are required, including continuing improvements in technical infrastructure. Interfirm networks can help to strengthen the overall potential of local centers, this being a precondition for the increase of interdependence, in place of the total dominance of the core city within the metropolitan region.

One has to agree with the presumption that the development of economic activity in the region's hinterland areas has to rely on the combined effects of diffusion from the core and the activation of local, endogenous resources. According to the urban-rural regions concept referred to earlier in this article, the role of environmental assets is becoming particularly important among such local resources. A number of studies (ESPON 2010a: 73; Heffner 2012) have indicated that environmentally attractive rural zones tend to evolve in the direction of so called consumption landscapes, or consumption countryside areas. These functions in turn generate new economic activities in part by altering the farming profile, but most of all by creating a demand for new service sector activities, including advanced services, for example in the sphere of education and culture. While offering a new development perspective to some smaller urban localities situated in peripheral areas of the region, such changes contribute to the evolution of city-hinterland relations towards a functional pattern which can be characterized as cohesion through complementarity (Roo 2012).

Which of the hypothetical future development paths among those indicated in Section 2 should then be regarded as a realistic perspective for Warsaw region in mid-term? In accordance with contemporary approaches to the study of metropolitan regions, internal cohesion and interdependence are factors that strongly bear on the regions' competitive position within broader, i.e. national and international settlement systems. Functional interdependence can be achieved under different models of spatial organization, including polycentric and urban-rural.
Polycentric development, of the kind represented in the concept of European Metropolitan Regions, is basically precluded in the case of the Warsaw region due to the existing settlement structure in which there is a lack of real sub-dominant centers, i.e. larger cities, aside from Warsaw that could constitute prospective focal points for metropolitan functions. The recent years have in fact witnessed a growing intra-regional polarization, in both economic and demographic terms, as the city of Warsaw has been capitalizing on its new international position within the EU by attracting high-ranking activities together with in-migration flows. It is most likely that such a trend to polarization will be extended into the near future.

If this development path is followed, then the long- lasting process of concentration that has been observed in the settlement network within the hinterland area beyond the metropolitan ring is going to continue - in fact with a growing momentum under the creeping overall process of depopulation. This implies a clustering of population and economic activity, as well as public services and public institutions, in and around centers of intermediate rank at the cost of small, local, urban and rural localities. At the same time, the improvements in technical infrastructure will allow for some enlargement of spread effects, i.e. relocation of economic activity from Warsaw, mainly in terms of spillover to peri-urban zones, as well as a further spatial expansion of the city labor market.

From the point of view of intra-regional interdependence, the implications of the continuing spatial polarization are not totally clear. In the light of the survey results presented in the previous section, the city-hinterland linkages appear as an important dimension of the firms' activity in space, even though their presence was reported less frequently than that of intra-city and intra-hinterland ties, respectively. Still, as noticed earlier, the hinterland-based firms were found to be more active in the development of cooperative linkages at a local scale. All this provides little evidence for the loosening of the traditionally strong city-hinterland interrelations, the phenomenon for which globalization processes are frequently blamed. Nevertheless, if such a trend does in fact occur, it could be reversed, or at least moderated, in the future as a consequence of an expected increase in the scale of relocation of economic activity from the region's core to the hinterland area. The lat- 
ter development, however, could imply that an end to the intra-regional polarization process is approaching.

For economic spread effects to appear on a noticeable scale, the activation of the endogenous resources of the region's hinterland area, including its natural endowment, normally constitutes the crucial factor. An innovative way of using these assets may enable some areas to alter their traditional production profile, or to evolve into 'consumption spaces', and so become magnets for selective ex-urban migration. It may also permit smaller urban localities to differentiate their economic base by acquiring specialized activities, including knowledge intensive ones. In the case of the Warsaw region with its wide-ranging and varied rural countryside, such a development perspective seems to be particularly relevant in the mid-to-long term. It implies the persistence of a explicitly monocentric structure in the settlement system, one with a dominant urban core, a spatial extension and development of the periurban zone, and an increasingly poly-functional character in the predominantly rural hinterland with a network of small and medium-sized urban

\section{References}

ARING J., 2009. Europäische Metropolregionen: Annäherungen an eine raumordnerische Modernisierungsstrategie. [in:] J. Knieling (ed.), Metropolregionen und Raumentwicklung, Teil 3: Metropolregionen. Innovation, Wettbewerb, Handlungsfähigkeit, Forschungs- und Sitzungsberichte der ARL, no. 231, Hannover: Verlag der ARL, pp. 10-21.

BAŃSKI J., 2011. Uwarunkowania sukcesu gospodarczego na wsi. [in:] W. Kamińska, K. Heffner (eds.), Dychotomiczny rozwój obszarów wiejskich? Czynniki progresji, czynniki peryferyzacji, Studia KPZK PAN, no. 138, Warszawa: Komitet Przestrzennego Zagospodarowania Kraju PAN, pp. 61-76.

BATTY M., 2008. Fifty years of urban modeling: macro-statics to macro-dynamics. [in:] S. Albeverio, D. Andrey, P. Giordano, A. Vancheri (eds.), The dynamics of complex urban systems, Heidelberg-New York: Physica-Verlag, pp. 1-20.

Benz A., Borchard K., Eser T.W., Kujath H.J., Langhagen-Rohrbach Ch., Ritter E.-H., Scoen K.P., Toennies G., Wegener M., 2004. Why the EU needs settlements functionally interconnected at the local scale. At the same time, it may offer an acceptable level of territorial cohesion and intraregional integration based upon the functional complementarity of individual sub-regions.

Taking a more general view it is to be presumed that the spatial pattern, one defined in the concept of the urban-rural region, represents a coherent evolutionary path for the Warsaw metropolitan region. Such a development, it can be argued, would profit both the city of Warsaw and the region as a whole. It implies the spread of some advanced, specialized functions from the region's urban core, an effective use of the endogenous resources of the hinterland areas, and the formation of preconditions for the development of complementarities between individual zones and sub-centers within the region. It should therefore be recognized and promoted by spatial policy at both regional and interregional levels.

Editors' note:

Unless otherwise stated, the sources of tables and figures are the author(s), on the basis of their own research.

a European spatial development policy. Position Paper from the ARL, no. 60, Hannover: Akademie für Raumforschung und Landesplanung, 19 pp., http:// shop.arl-net.de/media/direct/pdf/pospaper_60_ engl.pdf [1 April 2013].

BERRY B.J.L., 1973. Growth centers in the American urban system. Vol. 1. Community development and regional growth in the Sixties and Seventies. Cambridge (Massachusetts): Ballinger Publishing Company, 195 pp.

BerRY B.J.L., Horton F. (eds.), 1970. Geographic perspectives on urban systems. Englewood Cliffs, N.J.: Prentice-Hall , 564 pp.

Bogue, D.J., 1949. The structure of the metropolitan community; a study of dominance and subdominance. Ann Arbor, MI: Horace H. Rackham School of Graduate Studies, University of Michigan, $210 \mathrm{pp}$.

BouRne L.S., 1999. Governance, efficiency and social equity in large urban agglomerations: Examples from the recent Toronto experience. [in:] A.G. Aguilar, J. Escamilla (eds.), Problems of megacities: Social inequalities, environmental risk and urban governance, 
Mexico City: Universidad Nacional Autonome de Mexico, 668 pp.

ChOJniCKI Z., 1988. Koncepcja terytorialnego systemu społecznego. Przegląd Geograficzny, vol. 60, no. 4, pp. 491-510.

Czyż T., 2011a, Conceptions of an urban agglomeration and a metropolitan area in Poland. Geographia Polonica, vol. 84, no. 2, pp. 5-17.

Czyż T., 2011b. Przemiany struktury przestrzenno-ekonomicznej Polski w latach 1998-2008. [in:] P. Churski (ed.), Zróżnicowania regionalne w Polsce, Biuletyn KPZK PAN, no. 248, Warszawa: Komitet Przestrzennego Zagospodarowania Kraju PAN, pp. 45-59.

DegóRSKA B., 2012. Spatial growth of urbanised land within the Warsaw Metropolitan Area in the first decade of the 21st century. Geographia Polonica, vol. 85, iss. 3, pp. 77-95.

DOMAŃSKI B., 2008. Rozwój polskich metropolii a regiony peryferyjne. Bezpowrotna separacja czy współzależność rozwoju? [in:] T. Marszał (ed.), Rola polskich aglomeracji wobec wyzwań strategii lizbońskiej, Studia KPZK PAN, no. 120, Warszawa: Komitet Przestrzennego Zagospodarowania Kraju PAN, pp. 135-143.

DOMAŃSKI R., 2000. Miasto innowacyjne. Studia KPZK PAN, no. 109, Warszawa: Wydawnictwo Naukowe PWN Komitet Przestrzennego Zagospodarowania PAN, 192 pp.

Duncan O.D., Scott W.R., Lieberson S., Duncan B., Winsborough H.H., 1960. Metropolis and region. Baltimore: The Johns Hopkins University Press, 605 pp.

DZIEWOŃSKI K., 1975. The place of urban agglomerations in the settlement system of Poland. Geographia Polonica, vol. 30, pp. 9-19.

Dziewoński K., GaWryszeWSKI A., IWANICKA-LyROWA E., Jelonek A., Jerczyński M., WęCŁAWowicz G., 1977. Rozmieszczenie i migracje ludności a system osadniczy Polski. Prace Geograficzne, no. 117, Wrocław-Warszawa-Kraków-Gdańsk, Ossolineum, Instytut Geografii i Przestrzennego Zagospodarowania PAN, Warszawa, 343 pp.

Dziewoński K., Korcelli P. (eds.), 1981. Studia nad migracjami i przemianami systemu osadniczego w Poslce. Prace Geograficzne, no. 140, Wrocław-Warszawa-Kraków-Gdańsk-Łódź: Ossolineum, Instytut Geografii i Przestrzennego Zagospodarowania PAN, $267 \mathrm{pp}$.

EBERHARDT P., 1970. Rola wielkich miast w strukturze regionalnej powiqzań przestrzennych $w$ Polsce. Biuletyn KPZK PAN, no. 58, Warszawa: Polskie Wydawnictwo Naukowe PWN, 169 pp.
ESDP, 1999. European Spatial Development Perspective. Towards balanced and sustainable development of the territory of the European Union. Commission of the European Communities. Committee on Spatial Development, Luxembourg: European Commission, $82 \mathrm{pp}$

ESPON, 2004. Potentials for polycentric development in Europe. ESPON Project no. 1.1.1, ESPON Monitoring Committee, Luxembourg: ESPON Coordination Unit, 1000 pp. http://www.espon.eu/main/Menu_Projects/Menu_ESPON2006Projects/Menu_ThematicProjects/ [15 January 2013].

ESPON, 2006. Spatial scenarios and orientations in relation to the ESDP and cohesion policy. ESPON project no. 3.2, The ESPON Monitoring Committee, Luxembourg: ESPON Coordination Unit, 46 pp. http:// www.espon.eu/export/sites/default/Documents/Projects/ESPON2006Projects/CoordinatingCrossThematicProjects/Scenarios/fr-3.2_final-report_vol1.pdf [15 January 2013].

ESPON, 2010b. New evidence on smart, sustainable and inclusive territories. First ESPON 2013 Synthesis Report, Luxembourg: ESPON Coordination Unit, 107 pp. http://www.espon.eu/main/Menu_Publications/Menu_MapsOfTheMonth/FirstESPONSynthesisReport.html [15 January 2013].

ESPON, 2010a. Future orientations for cities. Final Scientific Report. ESPON Applied Research 2013/1/1, The ESPON Monitoring Committee, Luxembourg: ESPON Coordination Unit, 63 pp. http:// www.espon.eu/export/sites/default/Documents/ Projects/AppliedResearch/FOCl/FOCl_final_ report_20110111.pdf [16 January 2013].

FrIEDMANN J., 1986. The world city hypothesis. Development and Change, vol. 17, pp. 69-83.

Friedmann J., Miller J., 1965. The urban field. Journal of the American Institute of Planners, vol. 31, no. 4, pp. 312-320.

GaWryszewski A., 2005. Ludność Polski w XX wieku. Monografie, vol. 5, Warszawa: Instytut Geografii i Przestrzennego Zagospodarowania PAN, 623 pp.

GORZELAK G., 2007. Rozwój polskich regionów a polityka spójności Unii Europejskiej. [in:] G. Gorzelak (ed.), Polska regionalna i lokalna w świetle badań EUROREGu, Warszawa: Wydawnictwo Naukowe Scholar, pp. 12-34.

Gorzelak G., SMĘTKOWSKI M., 2005. Metropolia i jej region w gospodarce informacyjnej. Centrum Europejskich Studiów Regionalnych i Lokalnych, Warszawa: Wydawnictwo Naukowe Scholar, 224 pp.

Gras N.B.S., 1922. The development of metropolitan economy in Europe and America. American Historical Review, vol. 27, no. 4, pp. 695-708. 
Gutry-Korycka M. (ed.), 2005. Urban sprawl. Warsaw agglomeration case study. Warsaw: Warsaw University Press, $335 \mathrm{pp}$.

Hall P., Gracey H., Drewett R., Thomas R., 1973. The containment of urban England. Vol. 1-2. London: Allen and Unwin, Beverly Hills, Sage Publications, $648+464 \mathrm{pp}$.

Hall P., PAIN K., 2006. The polycentric metropolis. Learning from mega-city regions in Europe. London: Earthscan, 228 pp.

Heffner K., 2012. Ewolucja zróżnicowania poziomu rozwoju regionów w Polsce a potrzeba polityki spójności. [in:] A. Harańczyk (ed.), Perspektywy rozwoju regionalnego Polski w okresie programowania po 2013 r., Studia KPZK PAN, no. 140, Warszawa: Komitet Przestrzennego Zagospodarowania Kraju PAN, pp. 57-73.

IKER, 2008. Pierwszy ranking metropolitalności miast Polski. Nordea Metrox.2008. Poznań: Instytut Konkurencyjnej Ekonomii Regionów, http:// http://iker.org. pl/files/metrox_2008_LOW.pdf [15 May 2013].

JaŁOWIECKI B., 1999. Metropolie. Białystok: Wyższa Szkoła Finansów Publicznych w Białymstoku, 174 pp.

Komornicki T., CZapiewski K.Ł., Solon B. (eds.), 2012. Zagospodarowanie infrastrukturalne i kapitat fizyczny oraz policentryczność rozwoju Mazowsza. Trendy Rozwojowe Mazowsza, no. 4, Warszawa: Mazowieckie Biuro Planowania Regionalnego, 58 pp., http:// www.trendyrozwojowemazowsza.pl/sites/default/ files/www_trm_nr_4.pdf [19 January 2013].

Korcelli-Olejniczak E., 2010. Kształtowanie się regionu metropolitalnego Warszawy w świetle analizy zasięgu działalności przedsiębiorstw sektora zaawansowanych usług. Przeglad Geograficzny, vol. 82, no. 4, 573-592.

Korcelli-OlejnicZAK E., 2012. Region metropolitalny - pojęcie, struktura przestrzenna, dynamika. Prace Geograficzne, no. 235, Warszawa: Instytut Geografii i Przestrzennego Zagospodarowania PAN, 189 pp.

LIsowski A., 2010. Suburbanizacja w obszarze metropolitalnym Warszawy. [in:] S. Ciok, P. Migoń (eds.), Przekształcenia struktur regionalnych. Aspekty społeczne, ekonomiczne i przyrodnicze, Wrocław: Uniwersytet Wrocławski. Instytut Geografii i Rozwoju Regionalnego, $442 \mathrm{pp}$.

LIsowSKI P., 2000. Radom, w blasku czy cieniu Warszawy? Studia Regionalne i Lokalne, no. 4(4), pp. 113-132.

LISZEWSKI S., 2010. Metropolia jako przedmiot badań naukowych i obszar dynamicznych przemian przestrzennych oraz społeczno-gospodarczych. [in:] Cz. Romański, T. Śmiłowska (eds.), Procesy metropolizacyjne w teorii naukowej i praktyce, Warszawa: Główny Urząd Statystyczny, pp. 27-41.
Markowski T., Marszat T., 2006. Metropolie, obszary metropolitalne, metropolizacja. Problemy i pojęcia podstawowe. Warszawa: Komitet Przestrzennego Zagospodarowania Kraju PAN, 24 pp.

McKenzIE R.D., 1933. The metropolitan community. New York: McGraw-Hill, 352 pp.

MKRO, 2006. Leitbilder und Handlungsstrategien für die Raumentwicklung in Deutschland. Ministerkonferenz für Raumordnung, Berlin, 35 pp. http://www. bmvbs.de/cae/servlet/contentblob/31494/publicationFile/545/leitbilder-und-handlungsstrategienfuer-die-raumentwicklung-in-deutschland-2006.pdf [18 January 2013].

MRR, 2012. Koncepcja Przestrzennego Zagospodarowania Kraju 2030. Warszawa: Ministerstwo Rozwoju Regionalnego, 240 pp. https://www.mrr.gov.pl/ rozwoj_regionalny/Polityka_przestrzenna/KPZK/ Aktualnosci/Documents/KPZK2030.pdf [17 January 2013].

PARYSEK J., 2005. Miasta polskie na przełomie XX i XXI wieku. Rozwój i przekształcenia strukturalne. Poznań: Bogucki Wydawnictwo Naukowe, 247 pp.

Piorr A., Ravetz J., Tosics I., 2011. Peri-urbanisation in Europe. Forest \& Landscape University of Copenhagen, 146 pp. http://www.plurel.net/images/Peri_Urbanisation_in_Europe_printversion.pdf [18 January 2013].

PRED A., 1975. On the spatial structure of organizations and the complexity of metropolitan interdependence. Papers, Regional Science Association, vol. 35, no. 1, pp. 115-142.

ROO DE G., 2012. The adaptive region: a reconstruction. Paper presented at a conference on: Territorial development challenges - visions of Europe and Poland, 22-23 November, Warszawa: Ministerstwo Rozwoju Regionalnego, 27 pp. http://www.mrr.gov.pl/english/ News/Documents/02_Gert_de_Roo_Poland_minregdev_gdr_a.pdf [18 January 2013].

ROSNer A., 2011. Zróżnicowanie zaludnienia obszarów wiejskich w Polsce. Obszary zmniejszajqce zaludnienie i koncentrujqce ludność. [in:] W. Kamińska, K. Heffner (eds.), Dychotomiczny rozwój obszarów wiejskich? Czynniki progresji, czynniki peryferyzacji, Studia KPZK PAN, no. 138, Warszawa: Komitet Przestrzennego Zagospodarowania Kraju PAN, pp. 125-139.

SMETTKOWSKI M., 2007. Nowe relacje metropolia - region w gospodarce informacyjnej na przykładzie Warszawy i Mazowsza. [in:] G. Gorzelak (ed.), Polska regionalna i lokalna w świetle badań EUROREGu. Warszawa: Wydawnictwo Naukowe Scholar, 316 pp.

SMĘTKOWSKI M., 2010. Konwergencja wewnatrzregionalna $w$ europejskich makroregionach metropolitalnych. Studia Regionalne i Lokalne, no. 2(40), pp. 50-76. 
SWM, 2006. Strategia rozwoju województwa mazowieckiego do roku 2020 (aktualizacja). Samorzad Województwa Mazowieckiego, Warszawa: Mazowieckie Biuro Planowania Regionalnego, 192 pp. http:// www.mbpr.pl/user_uploads/image/PRAWE_MENU/ strategia\%20rozwoju\%20wojew\%C3\%B3dztwa\%20 mazowieckiego\%20do\%20roku\%202020/SRWM/ SRWM.pdf [19 January 2013].
ŚLESZYŃSKI P., 2007. Gospodarcze funkcje kontrolne w przestrzeni Polski. Prace Geograficzne, no. 213, Warszawa: Instytut Geografii i Przestrzennego Zagospodarowania PAN, 320 pp.

Wróbel, A., 1960. Województwo warszawskie. Studium ekonomicznej struktury regionalnej. Prace Geograficzne, no. 24, Warszawa: Instytut Geografii PAN, Państwowe Wydawnictwo Naukowe, 140 pp. 